\title{
EX-REACTOR TESTING FOR CARBON LOSS \\ FROM HTS CLADDING IN THE PRESENCE OF METAL FUELS
}

by

G. D. Hudman, D. D. Keiser, * and D. L. Porter

\author{
EBR-II Division \\ Argonne National Laboratory \\ 9700 South Cass Avenue \\ Argonne, Illinois 60439
}

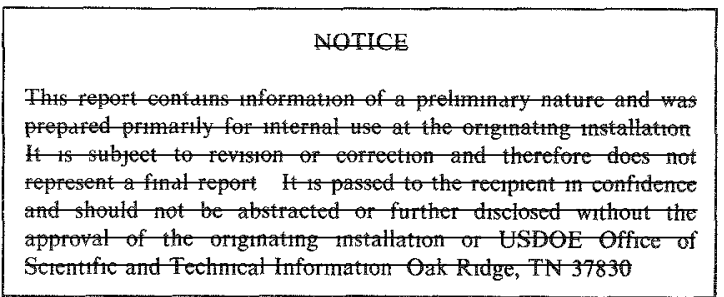

IFR TECHNICAL MEMORANDUM NO. 70

\section{Results reported in the IFR-TH series of memoranda frequently are pretiminary and subject to revision. consequentiy they should not be quoted or referenced without the authop's permission.}

\section{NO ACCESS RESTRICTIONS}

This document is not considered OUO-Applied Technology. It was reviewed for Export Controlled Information and found to be suitable for unlimited access and reproduction.

An
the
$m$
U.
re
$m$

This label reflects Applied Technology instructions issued April 13,

2006, by the the Department of Energy Office of Nuclear Energy. Additional guidance has also been provided by DOE in 2016 and 2018 memos, as well as from NNSA.

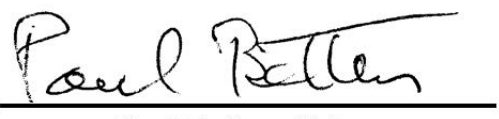

Paul Betten, ANL data

vernins of Sec-

* Now a graduate student at Idaho University. 


\section{DISCLAIMER}

This report was prepared as an account of work sponsored by an agency of the United States Government. Neither the United States Government nor any agency thereof, nor any of their employees, makes any warranty, express or implied, or assumes any legal liability or responsibility for the accuracy, completeness, or usefulness of any information, apparatus, product, or process disclosed, or represents that its use would not infringe privately owned rights. Reference herein to any specific commercial product, process, or service by trade name, trademark, manufacturer, or otherwise does not necessarily constitute or imply its endorsement, recommendation, or favoring by the United States Government or any agency thereof. The views and opinions of authors expressed herein do not necessarily state or reflect those of the United States Government or any agency thereof. 


\section{DISCLAIMER}

This report was prepared as an account of work sponsored by an agency of the United States Government. Neither the United States Government nor any agency Thereof, nor any of their employees, makes any warranty, express or implied, or assumes any legal liability or responsibility for the accuracy, completeness, or usefulness of any information, apparatus, product, or process disclosed, or represents that its use would not infringe privately owned rights. Reference herein to any specific commercial product, process, or service by trade name, trademark, manufacturer, or otherwise does not necessarily constitute or imply its endorsement, recommendation, or favoring by the United States Government or any agency thereof. The views and opinions of authors expressed herein do not necessarily state or reflect those of the United States Government or any agency thereof. 


\section{DISCLAIMER}

Portions of this document may be illegible in electronic image products. Images are produced from the best available original document. 


\section{TABLE OF CONTENTS}

Page

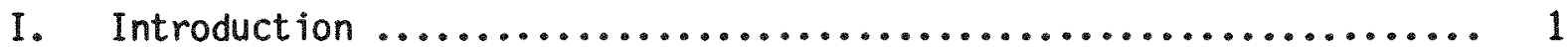

A. Relative Stability of Carbides ......................... 1

B. Carbon Loss from Ferritic Stainless Steels ................. 2

C. Effects of Carbon Loss on Mechanical Properties ............. 2

II. CARBON TRANSFER IN U-10Zr/HT9 FUEL ELEMENTS $\ldots \ldots \ldots \ldots \ldots \ldots \ldots \ldots$

A. Experimental Details ................................ 4

B. Bulk Carbon Analyses ................................. 7

C. Metallography ................................... 14

III. DISCUSSION AND CONCLUSIONS ........................... 20

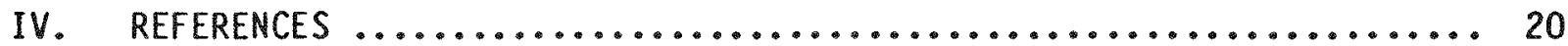


1. The $510^{\circ} \mathrm{C}$ Tensile Properties of Decarburized and Therma $17 y$ Aged $2.25 \mathrm{Cr}-1$ Mo Stee 1 [2] .............................. 5

2. Creep-Rupture Curves for Aged and Decarburized $2.25 \mathrm{Cr}-1$ Mo steel tested at $566^{\circ} \mathrm{C}$. The steel was thermally aged or decarburized for $26500 \mathrm{~h}$ at $566^{\circ} \mathrm{C}$. For comparison, average and minimum curves for annealed $2.25 \mathrm{Cr}-1$ Mo steel (as-heat-

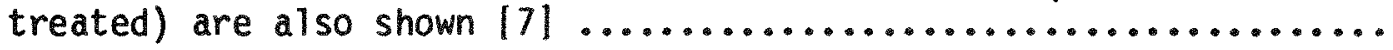

3. Experimental Capsules and Fuel Element Contained Within Used in the Carbon Transfer Experiment

4. Measured Temperature Profile Within the Testing Furnace ...........

5. Carbon Concentration in U-10Zr Fuel and HT9 Cladding as a Function of Elevation and Heat Treatment Temperature ............. 10

6. Carbon Concentration in the Ni200 Shroud Tube as A Function of Elevation and Heat Treatment Temperature at 840 hours ...

7. Bulk Carbon Concentration in Fuel Slug (0.173-in. dia) as a Function of the Decarburized Wall Thickness of HTg Cladding $(0.230$ in. $\times 0.200$ in. $)$. The remaining HT9 wall contains the

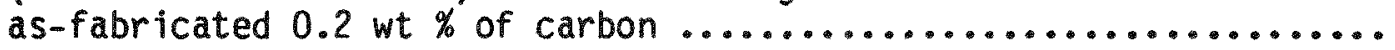

8. Carbon Content Remaining in the HTg Cladding after Decarburization of a Given Wall Thickness, Based on the Same

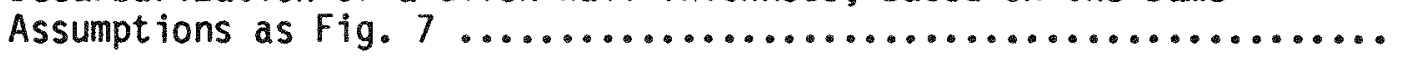

9. Carbon Content of HTg Cladding as a Function of the Decarburized Wal1 Thickness of the Ni200 Shroud Tube ..............

10. Optical Micrographs of Polished and Etched HT9 Cladding Samples at 840 hours. These samples are from sodium bonded areas, and correspond to the carbon contents shown in Fig. 5 below the sodium level .........................

11. Optical Micrographs of Polished and Etched HT9 Cladding Samples at $840 \mathrm{~h}$. These samples are the control specimens, sectioned from above the sodium level (see Fig. 5) .................

12. Microhardness Measurements Taken on Selected HT9 Cladding Metal lography Samples (840 hours). Data was taken at outer

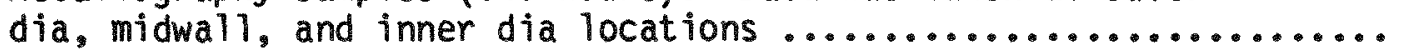

13. Optical Micrograph of HT9 Cladding in the Plenum (Control) Region Where Carbon Transferred Due to Physical Contact with the Ni200 Tube and/or Sodium Condensation at That Location. Note: The darkened area has a hardness of

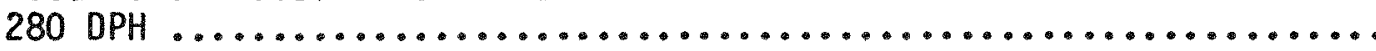




\section{LIST OF TABLE}

Page

I. The Effect of Carbon on the Room-Temperature Tensile

Properties of Normalized-and-Tempered 2.25Cr-1Mo Stee1 (4)........ 3 


\title{
EX-REACTOR TESTING FOR CARBON LOSS FROM HT9 CLADOING IN THE PRESENCE OF METAL FUELS
}

by

G. D. Hudman, D. D. Keiser, and D. L. Porter

\begin{abstract}
U-102r fuel elements clad in HTg and heated in an axial temperature gradient $\left(500-700^{\circ} \mathrm{C}\right)$ were sectioned after 840 and $2325 \mathrm{~h}$ of heat treatment to look for carbon transfer from the HT9 cladding $(0.2$ wt $\%$ C) to the $U-102 r$ fuel $(100 \mathrm{ppm} \mathrm{C)}$. The element had been encapsulated and sodium bonded in a nickel 200 capsule. It was assumed that carbon would not transfer between the $\mathrm{Ni}$ and HTg tubes, at least from HT9 to Ni200. Results obtained, however, showed that $C$ did transfer from the $N i$ $(0.08$ wt \%) to the HTS cladding. There was no evidence of transfer from the HT9 to the fuel despite the extensive carburization of the HT9 cladding. There was therefore no strong tendency found for carbon to transfer from the HT9 cladding to the fuel to temperatures of $700^{\circ} \mathrm{C}$ and times of 2325 hours. Recent post-irradiation testing of 3 at.\% burnup X425 fuel elements support this finding. In addition, a literature review indicates that carbon loss alone may not result in significant reductions in creep rupture life; recrystallization and grain growth at high temperatures resulting from loss of carbides causes the most significant strength reductions.
\end{abstract}




\section{INTRODUCTION}

The sodium bonded fuel system of U-10Zr or U-xPU-10Zr fuel with HT9 (12 $\mathrm{Cr}-1 \mathrm{MO})$ for advanced reactor systems has raised questions as to the possible carbon transfer from cladding to fuel during reactor operation. The loss of carbon from the cladding could potentially degrade the strength and creep resistance of the HT9 and shorten fuel element 1 ifetimes. It is the purpose of this study to discover the propensity for cladding-to-fuel carbon migration and to assess the possible consequences.

\section{A. Relative Stability of Carbides}

At room temperature chromium carbides have a free energy of formation $(\Delta F)$ of -17 to $-10 \mathrm{kca} / \mathrm{g} \cdot$ atom of carbon, depending on the type of carbide formed: $\mathrm{Cr}_{23} \mathrm{C}_{6}$ is most stable. Uranium carbides have a $\Delta F$ of -20 to $-10 \mathrm{kcal} / \mathrm{g} \cdot$ atom of $\mathrm{C}$, the UC form being the most stable. ZrC is most stable with a $\Delta F$ of $-40 \mathrm{kcal} / \mathrm{g}$. atom of carbon. Note that the $\Delta F$ values change very little with temperature so the order of stabilities remain as given to fuel operating temperatures. In addition, zirconium can dissolve a great deal of carbon and thermodynamic quantities for this process are not well known. The important factor is that zirconium carbides could form at the expense of those which form in HT9, if those carbides which form in the steel before or during irradiation are sufficiently unstable at operating temperatures so that they will decompose and allow carbon diffusion.

There is some encouraging qualitative information implying that carbon transfer may not occur. For many years EBR-II has used solution-annealed Types 304 and 316 austenitic stainless steels for cladding. Although the fuel elements begin irradiation with the carbon dissociated and in solution in the cladding, optical metallography of cladding after irradiation has shown a sensitized structure where carbides have formed and remain stable at the grain boundaries. While these results are encouraging, extending the observations to HT9 are difficult due to the facts that (1) HT9 is martensitic with carbon diffusivities different from the austenitic alloys, (2) the carbide type which forms depends on cladding composition and structure, with the very stable $\mathrm{M}_{23} \mathrm{C}_{6}$ carbides having been found to predominate in irradiated 304 and 316 
stainless steels, and (3) HT9 contains three or four times the amount of carbon than present in standard austenitic alloys.

\section{B. Carbon Loss from Ferritic Stainless Steels}

It was shown in the previous section that zirconium carbides are more stable than are carbides present in HT9. Resistance to carbon loss from cladding to fuel is therefore dependent upon the stability of the temperinduced carbides in the $12 \mathrm{Cr}-1$ Mo alloy. Chopra, et al. [1] have shown this for a similar alloy, $9 \mathrm{Cr}-1 \mathrm{Mo}$, demonstrating that $\mathrm{M}_{6} \mathrm{C}$ carbides decompose more readily than $\mathrm{M}_{23} \mathrm{C}_{6}$ carbides and carbon loss to flowing sodium is much more likely at temperatures above $550^{\circ} \mathrm{C}$ if $\mathrm{M}_{6} \mathrm{C}$ carbides are predominant.

Microstructural studies of properly heat treated HT9 materials have shown that $M_{23} C_{6}$ carbides are most prevalent. This indicates that the carbon in tempered HT9 is present in the most stable form.

\section{Effects of Carbon Loss on Mechanical Properties}

Martensitic alloys have not been examined for the effects of carbon loss on mechanical properties, but $\mathrm{Fe}-2.25 \mathrm{Cr}-1$ Mo has been [2-7]. Fe-2.25 $\mathrm{Cr}-1 \mathrm{Mo}$ is most often used in a tempered bainite condition, which is similar to tempered martensite in that the tempering treatment causes carbide precipitation at bainite lath boundaries, stabilizing a very fine bainitic structure which produces the good high temperature stress rupture properties. In the same manner tempering normalized HT9 stabilizes the fine martensitic lath

structure. It is this fine structure that gives HT9 most of its hightemperature strength properties.

It is therefore not clear that (1) HT9 will have unstable carbides at fuel/cladding operating temperatures and lose carbon to the fuel or (2) that if carbon is lost that reductions in strength would occur through instability of the fine lath structure resulting in growth of ferrite grains.

Klueh [4] has demonstrated that variations in carbon additions, and subsequent normalize-and-temper heat treatment, results in variations in yield and tensile strength in $2.25 \mathrm{Cr}-1$ Mo steel as shown in Table $\mathrm{I}$. 
TABLE I. The Effect of Carbon on the Room-Temperature Tensile Properties of Normalized-and-Tempered $2.25 \mathrm{Cr}$-1Mo Steel (4).

\begin{tabular}{lcc} 
& \multicolumn{2}{c}{ Strength (ksi) } \\
\cline { 2 - 3 } Carbon (wt \%) & 0.02 Yield & Tensile \\
\hline 0.009 & 36.8 & 60.2 \\
0.010 & 36.3 & 59.2 \\
0.030 & 42.3 & 61.4 \\
0.042 & & 76.4 \\
0.120 & 51.8 & 94.3 \\
0.135 & 77.9 & 100.7 \\
\hline
\end{tabular}


Microstructural examinations showed that less than 0.030 wt\% carbon results in a predominantly large-grain ferrite microstructure. With more carbon, bainite contents increase and a corresponding increase in strength is observed. Licina and Roy [2] and Chopra [5] have shown that if the $2.25 \mathrm{Cr}-1$ Mo bainitic material is decarburized at temperatures $727^{\circ} \mathrm{C}$, there are no significant reductions in high-temperature strength to very low carbon levels compared to strengths of material aged at $510^{\circ} \mathrm{C}$ but suffering no carbon loss. Licina and Roy results are shown in Figure 1. The conclusions are that the fine bainite structure is retained, despite carbon loss, and strength is retained. Temperatures of decarburization were not high enough to cause recrystallization and ferrite grain growth.

of more importance to fuel element cladding mechanical integrity is that Klueh [7] later showed that creep rupture behavior is also not significantly impaired by similar treatments (see Figure 2). Klueh used equal decarburizing and aging temperatures $\left(566^{\circ} \mathrm{C}\right)$. The martensitic alloy HT9 could possibly behave similarly if carbon were lost but no grain growth resulted. This will be the study of future experiments. The purpose of the present work is to determine the probability that HT9 will lose carbon to IFR fuels at normal operating temperatures.

\section{CARBON TRANSFER IN U-10Zr/HT9 FUEL ELEMENTS}

A test was designed to investigate whether carbon would transfer from HT9 cladding to U-10Zr at typical operating temperatures. Sodium provides an excellent transfer medium so fuel/cladding contact should not be required. The test was therefore to use as-fabricated 0.230 -in. diameter fuel elements $\left(\mathrm{U}-10 \mathrm{Zr}\right.$, HT9 clad) and heat them in a temperature gradient $\left(500-700^{\circ} \mathrm{C}\right)$ for 840 and $2325 \mathrm{~h}$. Bulk carbon analyses and metallography were then used to investigate for carbon transfer.

\section{A. Experimental Details}

Figures 3 and 4 show the design of the capsules used in the experiments, and the temperature profile imposed on them during testing. The profile was determined by moving a thermocouple axially, and the permanent thermocouple 


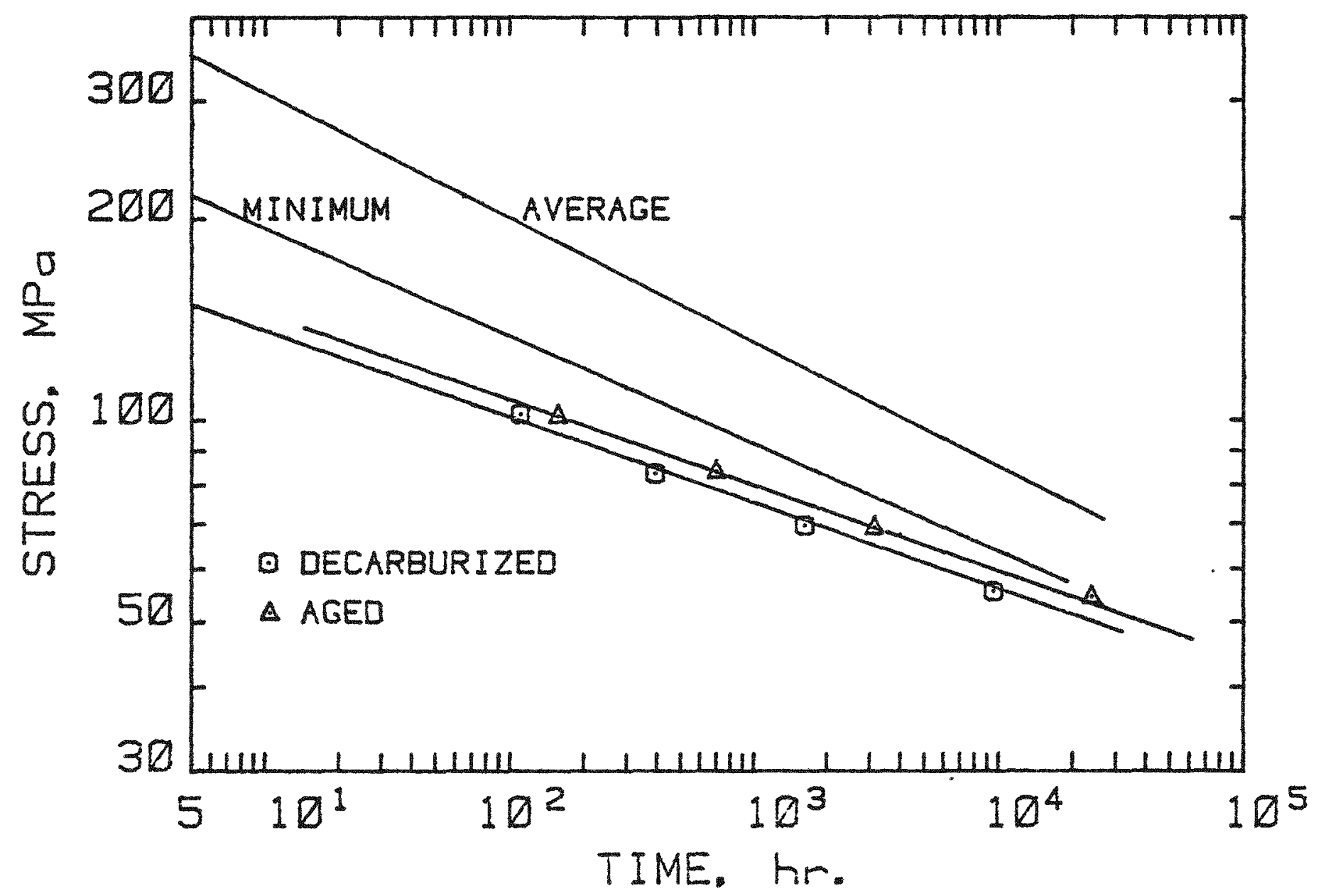

Figure 1. The $510^{\circ} \mathrm{C}$ Tensile Properties of Decarburized and Thermally Aged $2.25 \mathrm{Cr}-1$ Mo Steel [2] 


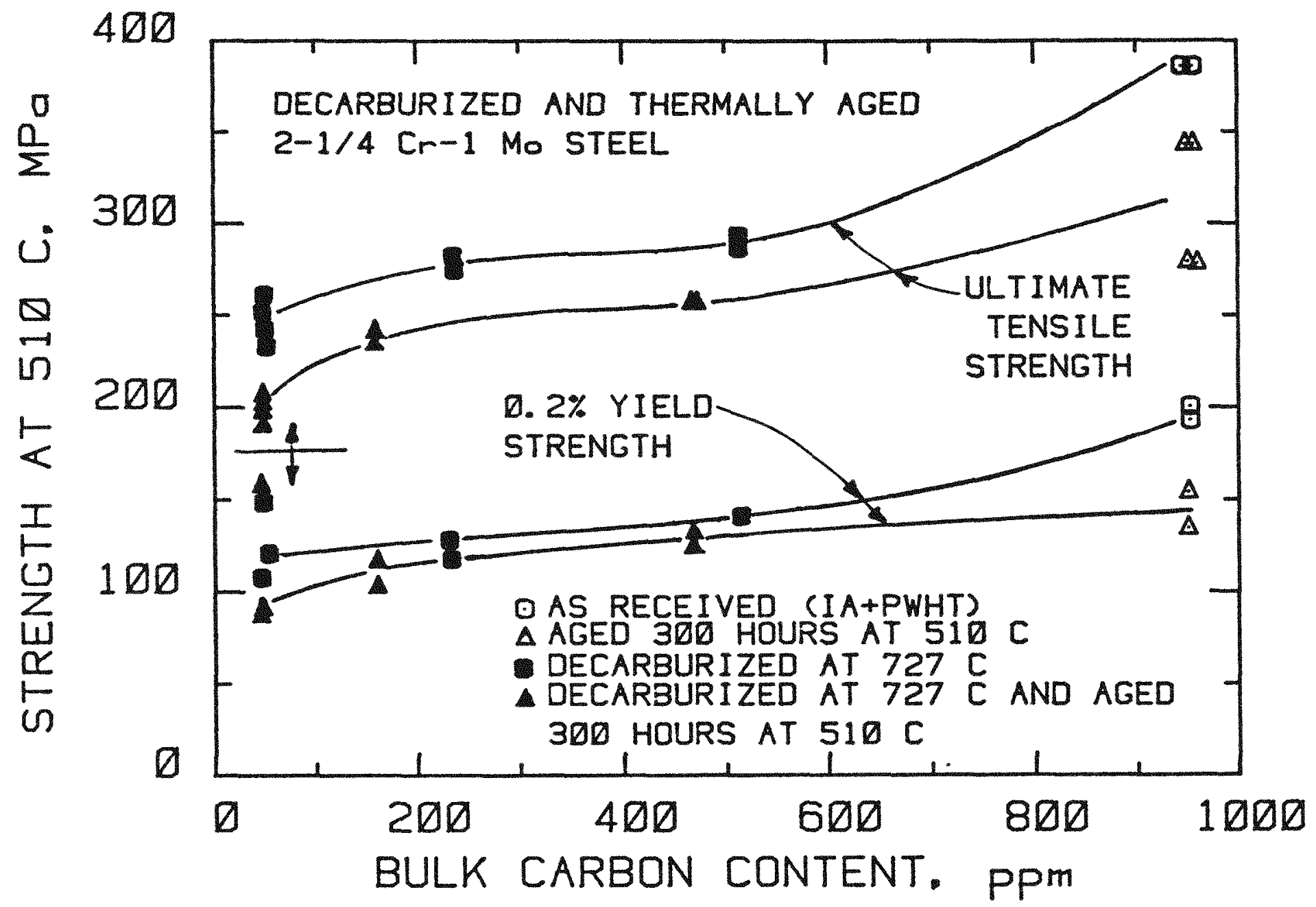

Figure 2. Cregp-Rupture Curves for Aged and Decarburized $2.25 \mathrm{Cr}$-1Mo Steel Tested at $566^{\circ} \mathrm{C}$. The steel was thermally aged or decarburized for $26500 \mathrm{~h}$ at $566^{\circ} \mathrm{C}$. For comparison, average and minimum curves for annealed $2.25 \mathrm{Cr}-1$ Mo steel (as-heat-treated) are also shown [7]. 
positions during heat treatment are shown in Fig. 4. The negative temperature gradient above the fuel column allowed use of this section as a control; note that no bond sodium exists in that region, and therefore no carbon transfer should occur.

Axial sections approximately $0.2-$ in. long were taken through the cladding and fuel slug at locations representing $500,550,600,650$, and $700^{\circ} \mathrm{C}$ (bonded) positions and through the cladding at $700,650,600,550$, and $500^{\circ} \mathrm{C}$ (unbonded) positions. Bulk carbon analyses were performed on the five fuel sections and the ten cladding sections. Metallography and microhardness tests were performed on cladding samples, metallography only was performed on the fuel.

\section{B. Bulk Carbon Analyses}

Figures 5 and 6 show the results of bulk carbon analyses. The cladding values show that the original carbon concentration $(0.2 \mathrm{wt} \%$ or $2000 \mathrm{ppm})$ exists in the control region of the capsule above the sodium level, although a slight increase is noted at high temperature positions. In the lower region, where bond sodium was present, the HT9 increased in carbon concentration. The increase in carbon was much greater at $700^{\circ} \mathrm{C}$ than other temperatures and increased with time. All sections showed an increase to at least $3000 \mathrm{ppm}$ of carbon. The $700^{\circ} \mathrm{C}$ samples had up to 1 wt \% carbon, or five times the original concentration. The fuel sample concentrations showed the usual scatter, but were all near the original composition of approximately $100 \mathrm{ppm}$ of carbon, and no trend was observed in the scatter with temperature, or with time.

In order to better understand the sensitivity that bulk measurements would give for transfer from the cladding to the fuel, several plots were made showing the expected bulk analysis for fuel and cladding if a given thickness of the HT9 cladding wall were totally decarburized and the remainder lost no carbon. These plots appear as Figures 7 and 8 . Note from Figure 7 that 20$30 \%$ of the wall would have to be decarburized to assure a positive reading of carbon transfer as measured by bulk fuel composition only. The lack of a trend with temperature in the fuel composition data shown in Figure 5 is therefore the best indication that there was no strong tendency to transfer carbon from the cladding to the fuel. 


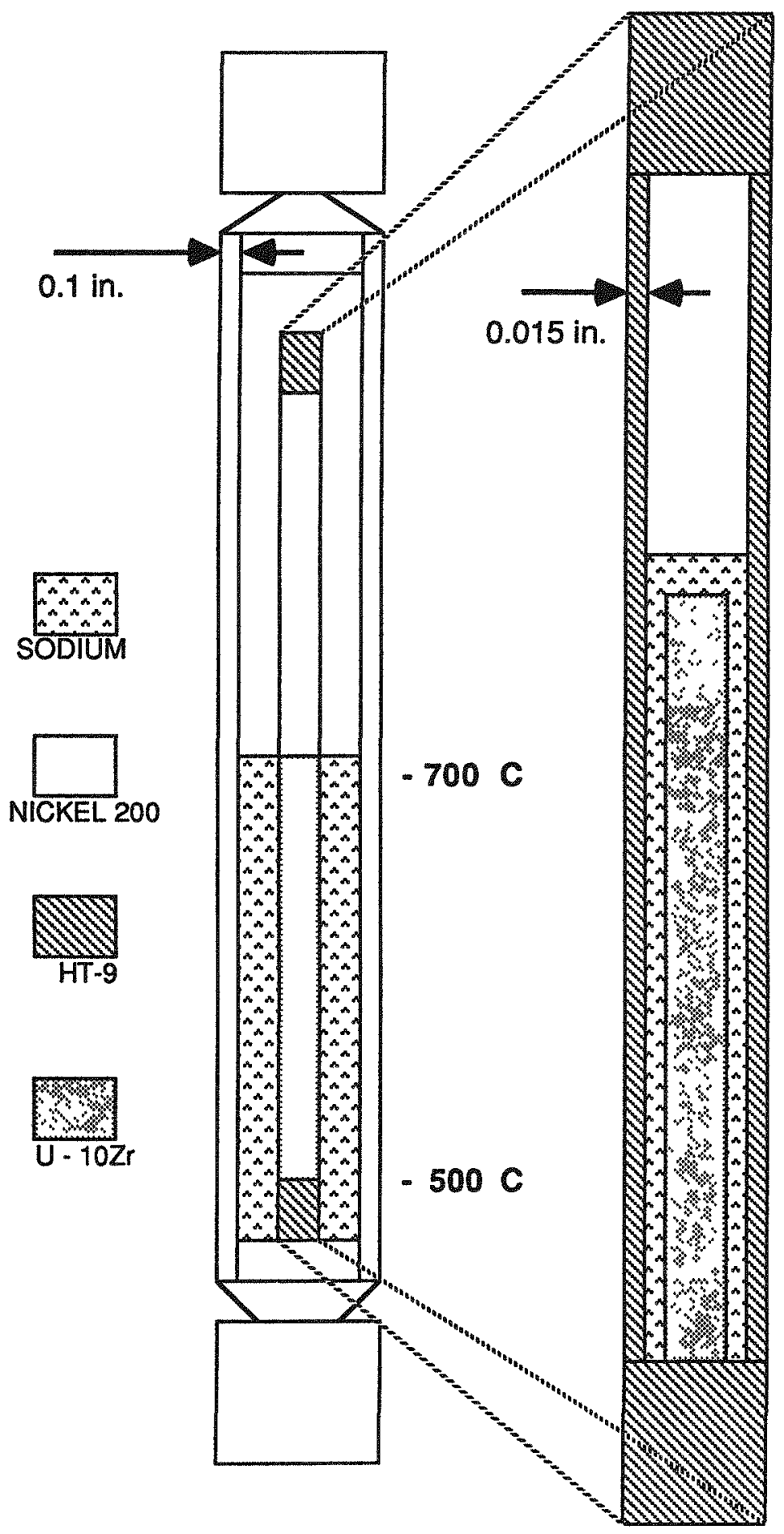

Figure 3. Experimental Capsules and Fuel Element Contained within Used in the Carbon Transfer Experiment 


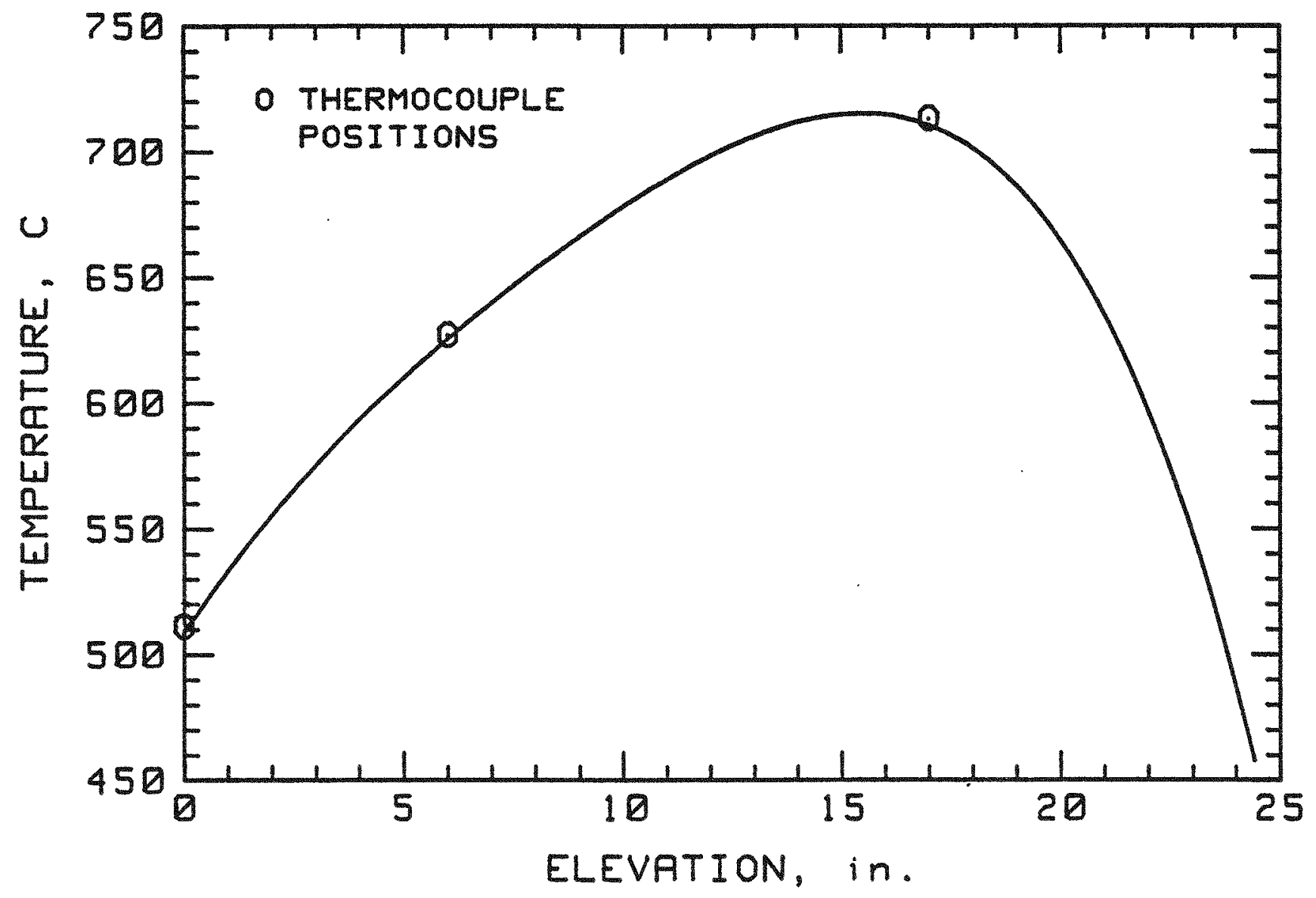

Figure 4. Measured Temperature Profile within the Testing Furnace 


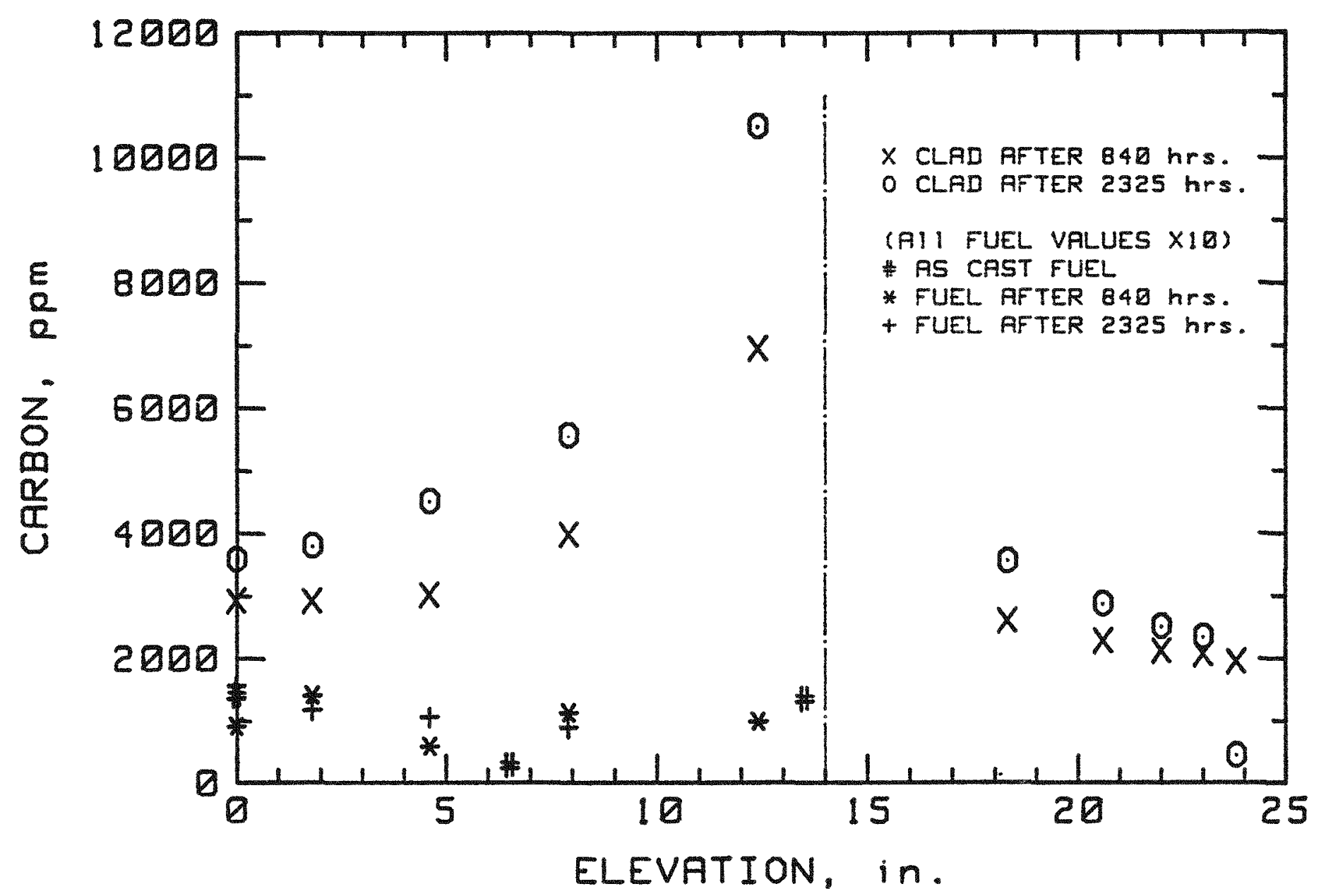

Figure 5. Carbon Concentration in U-10Zr Fuel and HTg Cladding as a Function of Elevation and Heat Treatment Temperature. 


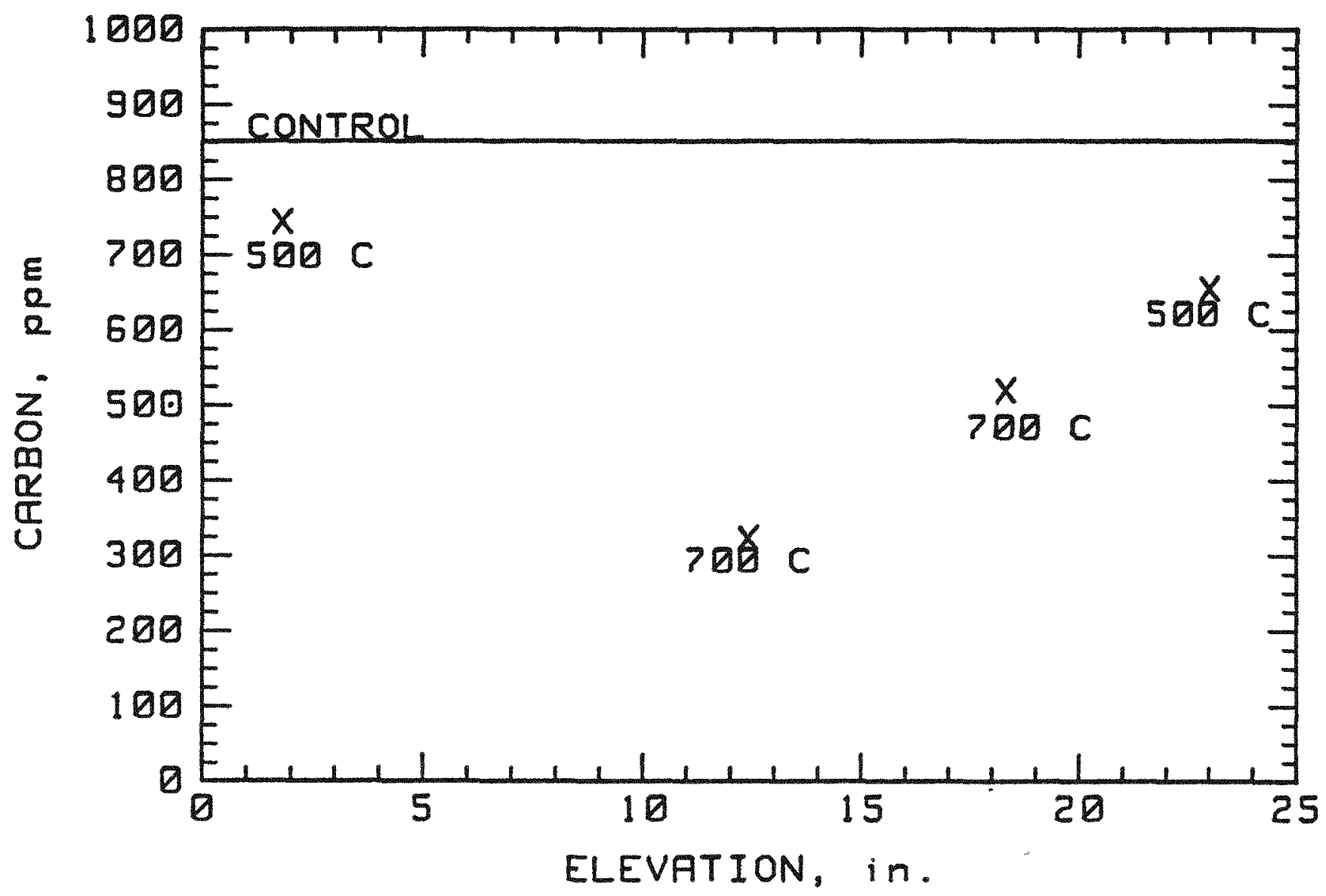

Figure 6. Carbon Concentration in the Ni200 Shroud Tube as a Function of Elevation and Heat Treatment Temperature at $840 \mathrm{~h}$. 


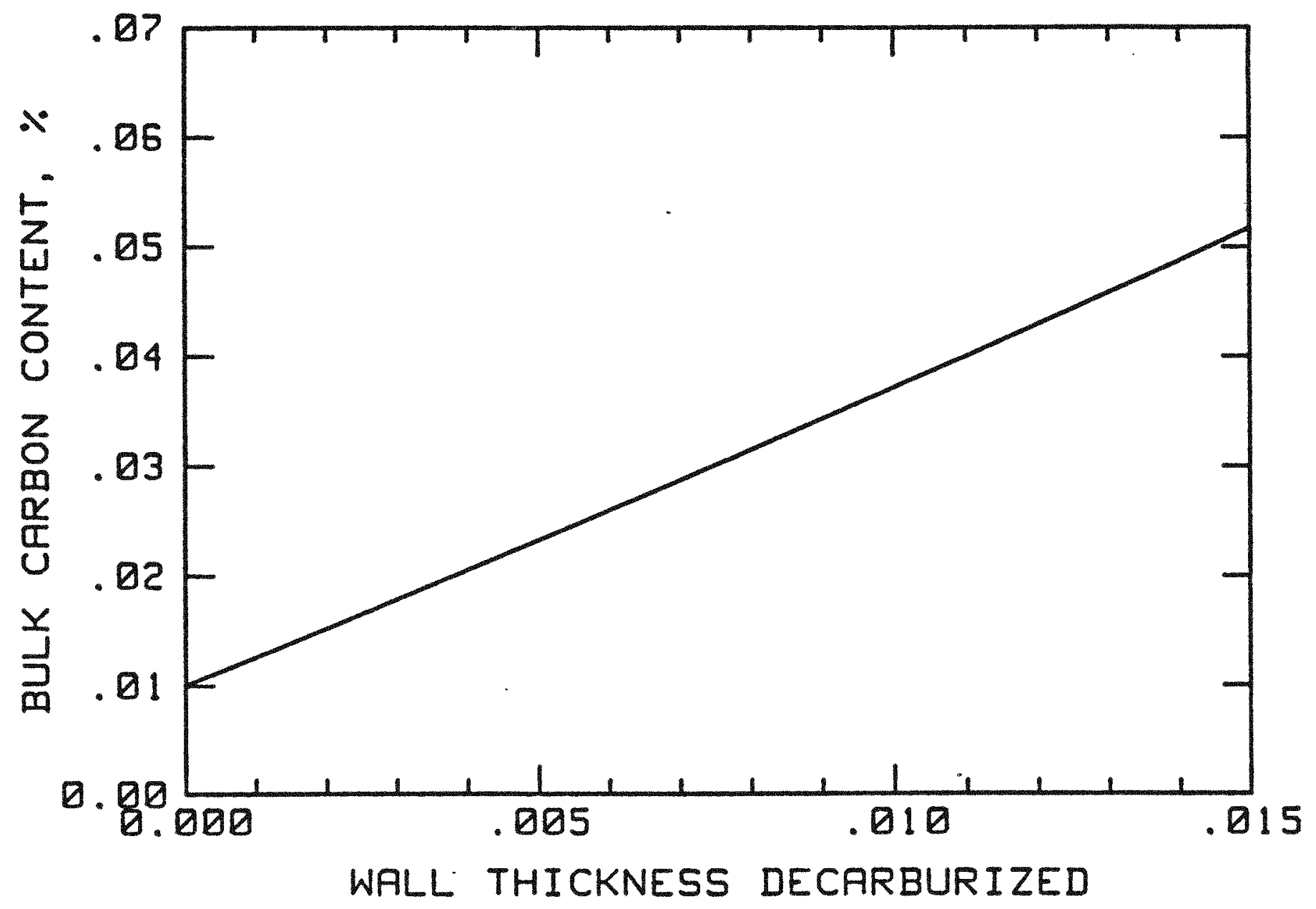

Figure 7. Bulk Carbon Concentration in Fuel Slug (0.173-in. dia) as a Function of the Decarburizated Wall Thickness of HT9 Cladding $(0.230 \mathrm{in} . \times 0.200 \mathrm{in}$.$) . The remaining HT9 wall contains the$ as-fabricated 0.2 wt $\%$ of carbon. 


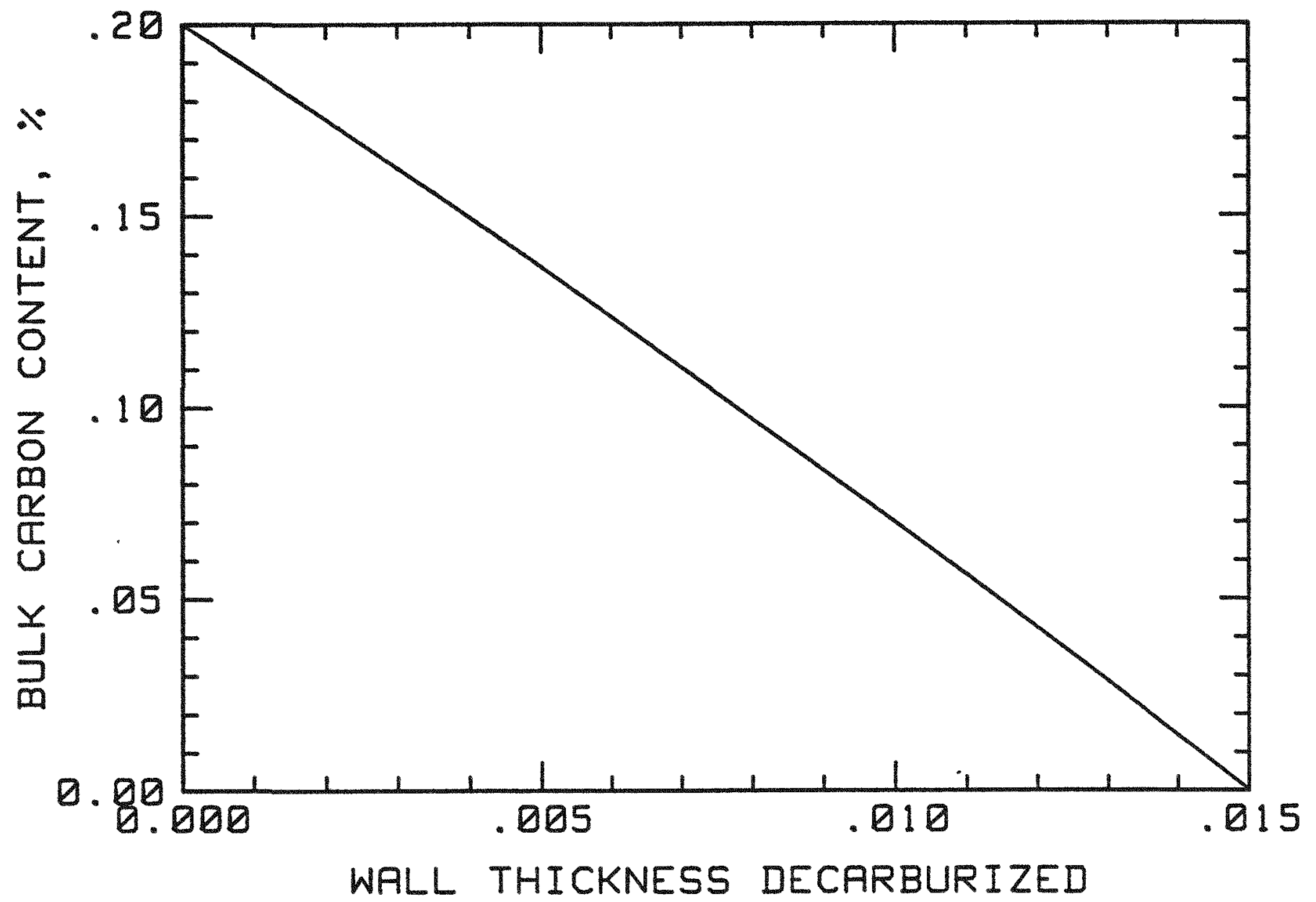

Figure 8. Carbon Content Remaining in the HT9 Cladding after Decarburization of a Given Wall Thickness, Based on the Same Assumptions as Fig. 7. 
The increase in carbon concentration in the cladding was indicated to have come from the bulk carbon concentrate (Fig. 6) and was metallographically confirmed to have resulted from carbon transfer from the Ni200 to the HT9. With the lack of strong carbide formers in Ni200 this could have perhaps been anticipated. Figure 9 shows a plot of what bulk carbon concentration would be measured, in an HT9 sample, as a result of decarburizing a given wall thickness of the Ni200 tube. Note that the concentrations measured would occur if approximately one-half of the wall thickness of the Ni200 tube had completely decarburized.

\section{Metallography}

Metallography of the U-10Zr fuel is not shown, but indicated no change in structure, particularly in the outer diameter regions. Figures 10 and 11 show micrographs of polished and etched sections of HT9 cladding after heat treatment for $840 \mathrm{~h}$. Note, in Figure 10, the dark bands on the outer diameter of the lower temperature sections, and that the entire cross-section of the $700^{\circ} \mathrm{C}$ sample appears dark. The samples taken above the sodium bond (Fig. 11) do not show this feature. Hardness data taken at 0.D. midwa 11, and I.D. areas of these samples show that the darkened areas are of higher hardness, while the I.D. areas show hardness levels equivalent to the areas above the sodium level (Fig. 12). This clearly shows that these areas are where the carbon has relocated after transfer from the Ni200 to the HT9. Metallography and hardness measurements from 2325 hour samples were consistent in that the darkened regions were more prevalent, but hardness values in general leveled out at 200-300 DPH.

The slight increase in carbon concentration of the HTg cladding in the unbonded plenum (control) region was due to physical contact between the cladding and the $\mathrm{Ni200}$ shroud tube and/or sodium condensation in that region. Figure 13 shows a micrograph of the HT9 cladding at a plenum location, revealing a dark area where the contact had occurred, and some carbon transferred to the HT9.

The carburization of the HT9 unfortunately obscures one-half of the data in that balances of bulk carbon concentrations between fuel and cladding are 


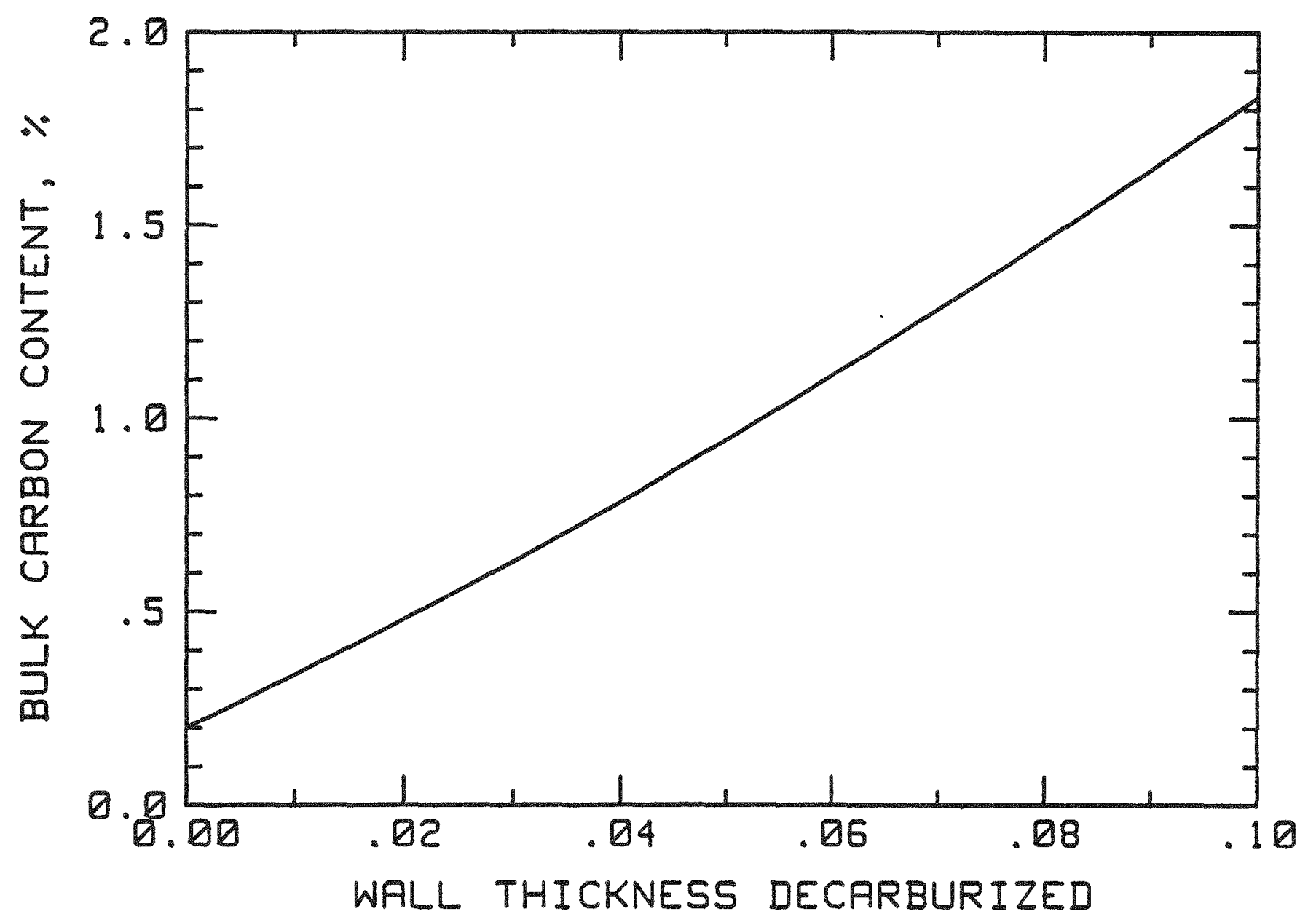

Figure 9. Carbon Content of HT9 Cladding as a Function of the Decarburized Wall Thickness of the Ni200 Shroud Tube. 


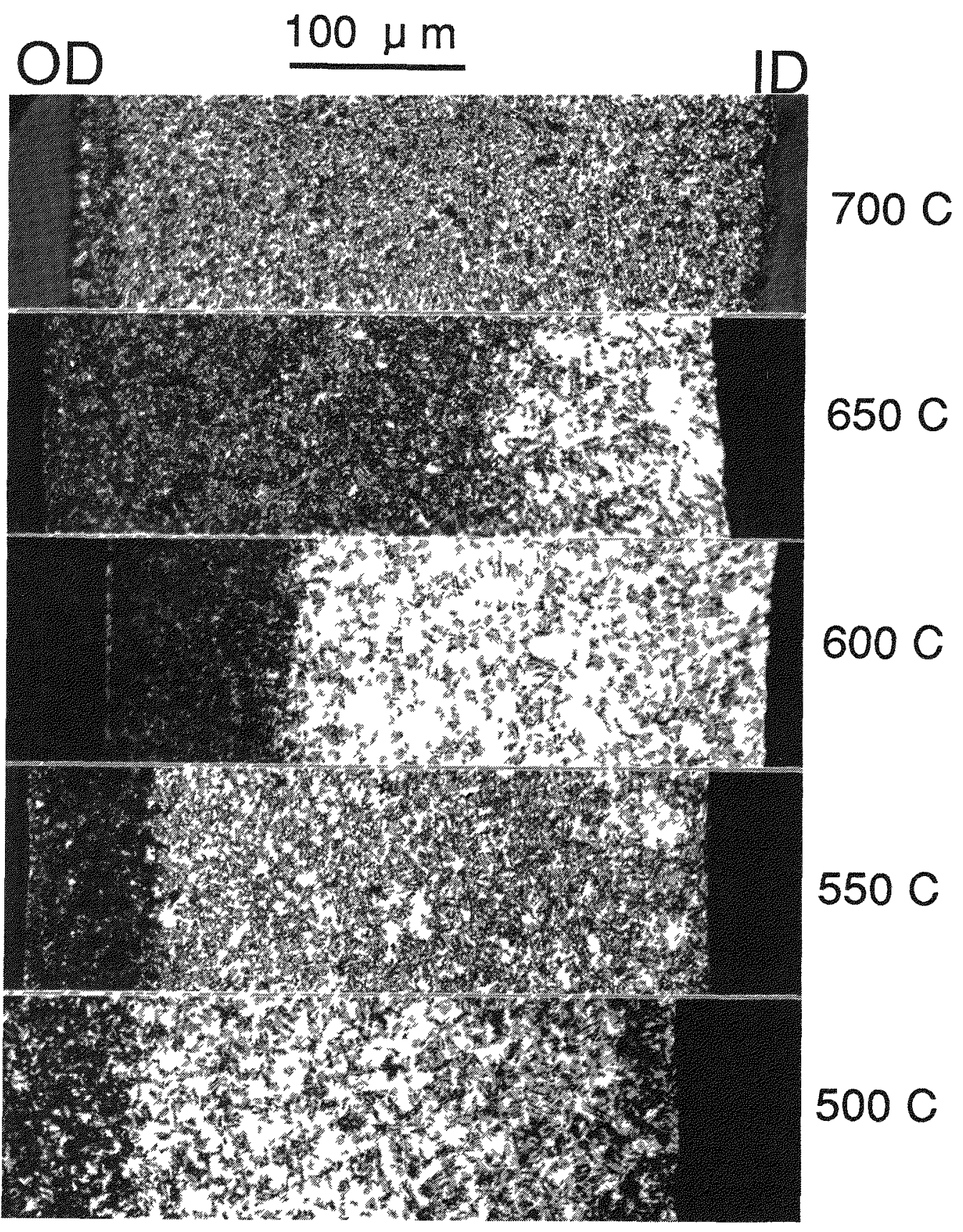

Figure 10. Optical Micrographs of Polished and Etched HT9 Cladding Samples at $840 \mathrm{~h}$. These samples are from sodium bonded areas, and correspond to the carbon contents shown in Fig. 5 below the sodrum level. 


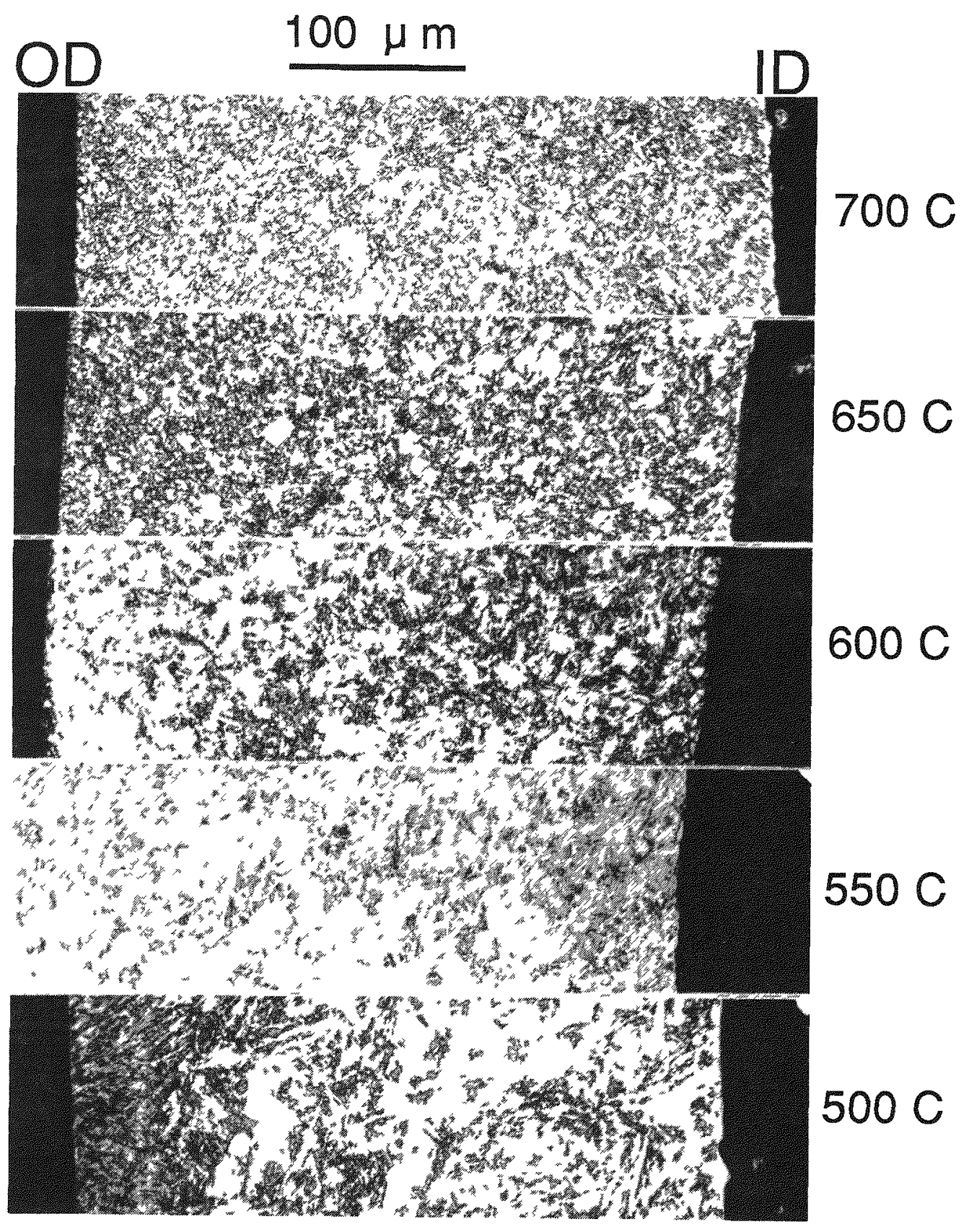

Figure 11. Optical Micrographs of Polished and Etched HT9 Cladding Samples at $840 \mathrm{~h}$. These samples are the control specimens, sectioned from above the sodium level (see Fig. 5). 


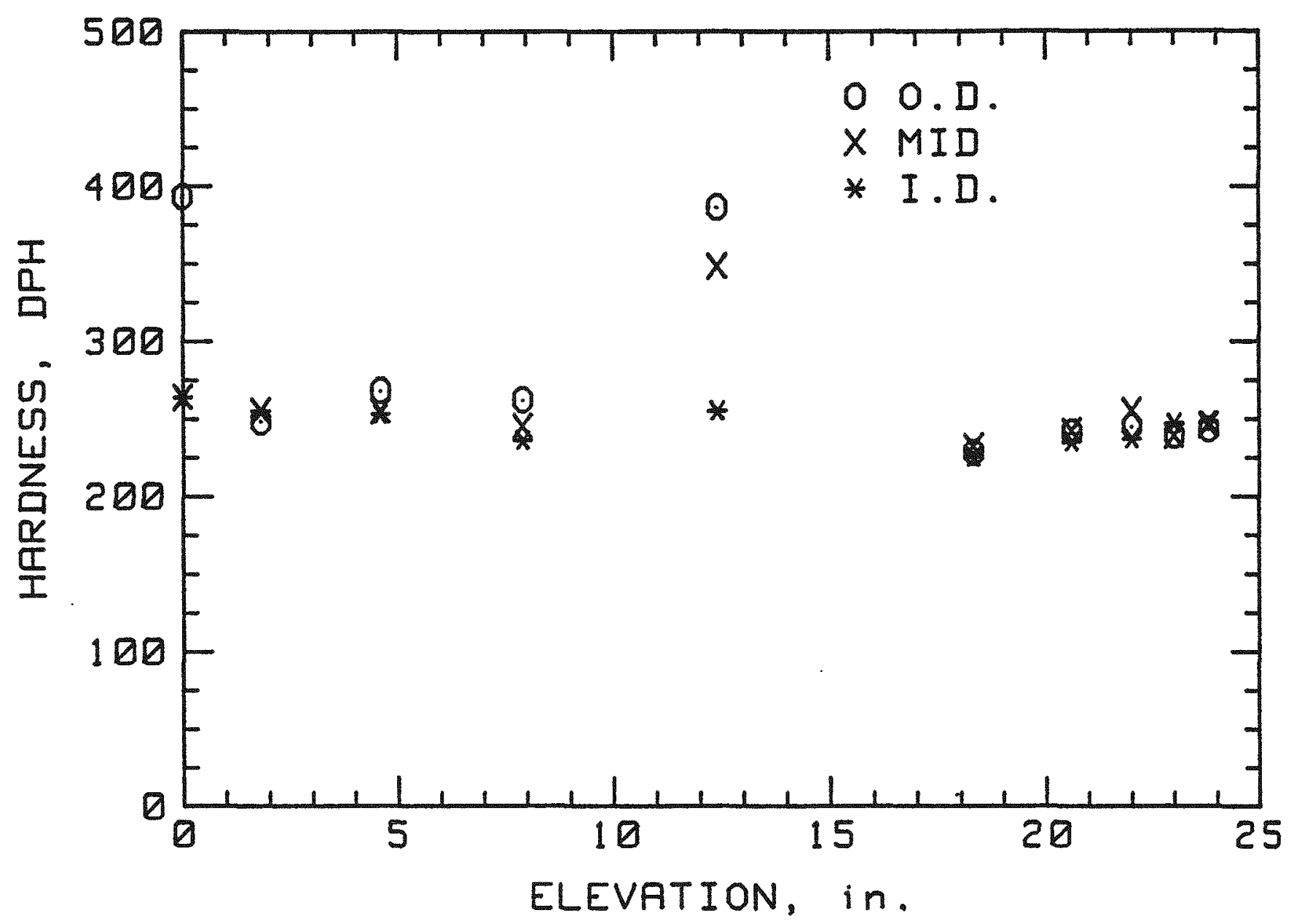

Figure 12. Microhardness Measurements Taken on Selected HT9 Cladding Metallography Samples $(840 \mathrm{~h})$. Data was taken at outer dia, midwall, and inner dia locations. 


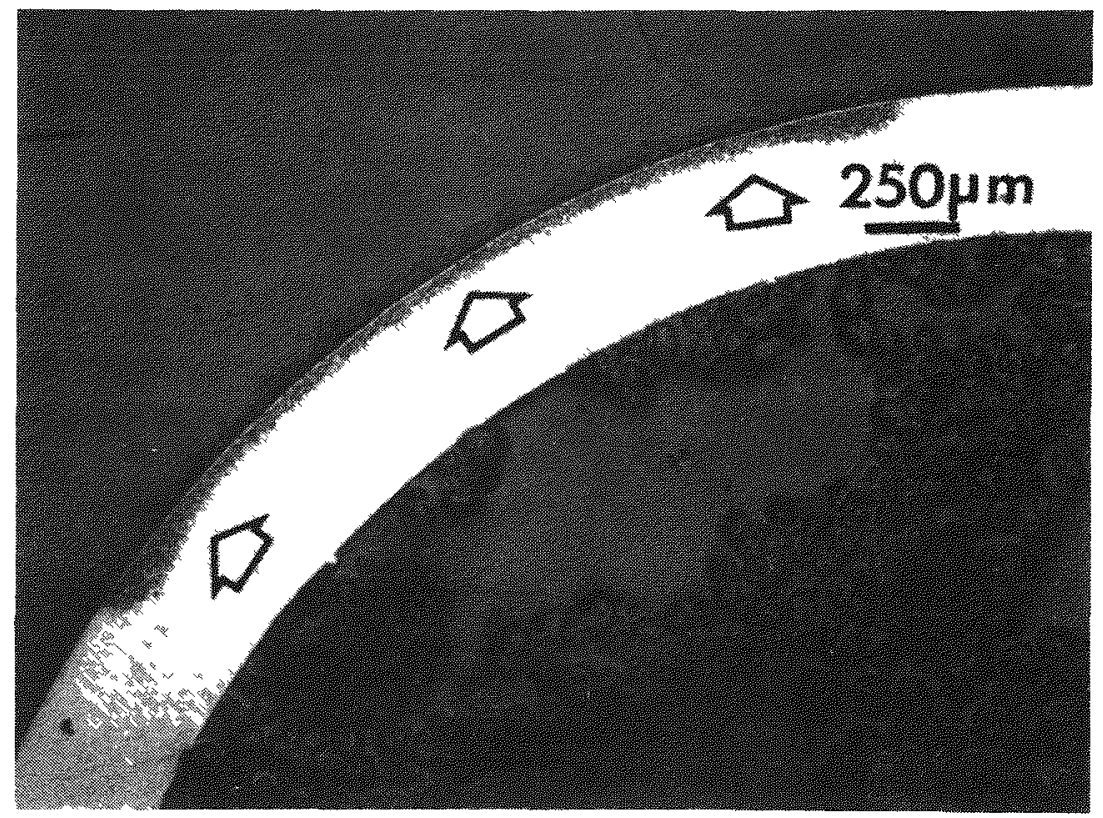

Figure 13. Optical Micrograph of HT9 Cladding in the Plenum (Control) Region Where Carbon Transferred Due to Physical Contact with the Ni200 Tube and/or Sodium Condensation at That Location. Note: The darkened area has a hardness of $280 \mathrm{DPH}$. 
not available for an extra check on the data. A possible benefit of the unexpected carburization, however, is that the carbon activity increases with increasing carbon content. While the kinetics of transfer may be diffusion controlled, the propensity to transfer as a function of temperature would certainly not be lessened by the carburization-induced carbon activity increase. If a threshold temperature exists for transfer the increased carbon activity could only reduce it. Moreover, the carburization layer thickness shows quite clearly that carbon can diffuse rapidly in HT9 at these temperatures.

\section{DISCUSSION AND CONCLUSIONS}

The results of the fuel element testing show that the tendency for carbon to transfer from HT9 cladding is minimal to temperatures of $700^{\circ} \mathrm{C}$. No such transfer was detected to aging times of 2325 hours. Review of literature further implies that if such carbon loss does eventually occur at long times, or as a result of the irradiation atmosphere, that significant loss of strength or stress rupture life may not occur if temperatures are not high enough to initiate recrystallization and grain growth.

The results of post-irradiation examinations of HT9-clad fuel elements at 3 at.\% burnup ( $X 425)$ support the findings of these studies in that microstructural and microhardness testing of the cladding showed no evidence of softening or changes in microstructure ident ified positively as carbon loss. The irradiation times of these elements were near 3500 hours and peak cladding temperatures approached $600^{\circ} \mathrm{C}$. While no carbon measurements were made these very prototypical testing results encourage conclusions that carbon loss effects on HT9 cladding integrity may not be expected for IFR fuel elements. 


\section{REFERENCES}

1. 0. K. Chopra, K. Natesan, and T. F. Kassner, "Carbon and Nitrogen Transfer in Fe-9Cr-Mo Ferritic Steels Exposed to a Sodium Environment," J. Nucl. Mater., 96, p. 269-284 (1984).

2. G. J. Licina and P. Roy, "Effects of Thermal Aging and Decarburization on the Mechanical Properties of $2.25 \mathrm{Cr}-1$ Mo Steel, "Proc. of the Third International Conf. on Liquid Metal Eng. and Tech., Oxford, England, April 9-13, 1984, Vo1. 3, p. 287-293 (1984).

3. R. R. Seeley and R. H. Zeisloft, "Effect of Carbon Content on HighTemperature Properties of $2.25 \mathrm{Cr}-1$ Mo Steels," ASTM STP 520, p. 332-334 (1973).

4. R. L. Klueh, "The Effect of Carbon on $2.25 \mathrm{Cr}-1$ Mo Steel (I). Microstructure and Tensile Properties," J. Nucl. Mater., 54, p. 41-54 (1974).

5. 0. K. Chopra, "Influence of Thermal Aging and Decarburization on the Tensile Properties of Fe-2.25 Cr-1 Mo Stee1," ANL-84-43 (February 1985).

6. G. P. Wozad1o, L. V. Hampton, and P. Roy, "Decarburization and Thermal Aging-The ir Effect Upon $2.25 \mathrm{Cr}-1$ Mo Steel Mechanical Properties, "Proc. of the Second International Conf. on Liquid Metal Technology, CONF-800401-P1, VC-79A, Richland, WA, p. 2-1 to 2-8 (April 20-24, 1980).

7. R. L. Klueh, "Creep of Decarburized and Aged $2.25 \mathrm{Cr}-1$ Mo Stee1," J. Nuc1. Mater., 96, p. 187-195 (1981). 